\title{
Survey of Larva Density of Aedes Aegypti In Mamuju Village, Mamuju Regency, West Sulawesi Province
}

\author{
Miftah Chairani Hairuddin ${ }^{1}$, Suhartina ${ }^{2}$,Zrimurti Mappau ${ }^{3}$ \\ \{miftahchairani@gmail.com ${ }^{1}$, suhartina.kesling@gmail.com², zmappau@gmail.com³
}

Poltekkes Kemenkes Mamuju ${ }^{1-3}$

\begin{abstract}
The population number of Aedes aegypti larvae is closely related to the increasing number of Dengue Haemorrhagic Fever (DHF) cases. This research was based on a problem occurred in 2014 in which 17 sufferers of dengue fever cases in Mamunyu village, Mamuju Regency, West Sulawesi Province. This research aims to know the population density of Aedes aegypti larvae by calculating the value of House Index (HI), Bretau Index (BI), and Density Figure (DI). The applied method was descriptive design with random sampling system. The data collection was done by conducting a direct survey through observation to each house. The results showed that the larval population in Mamunyu Village, Mamuju sub-district, was at moderate risk with density figure of 24 based on the results of the examination of HI (16\%), CI (2.4\%) and BI (20\%). These results were close to the predetermined threshold, that it has the potential to cause transmission of DHF. In conclusion, the population of Aedes aegypti larvae by looking at the examination results of $\mathrm{HI}, \mathrm{CI}$, and $\mathrm{BI}$ is close to the predetermined threshold. It suggests that the community, health workers, and related institutions paying attention in the availability of the larvae and doing early prevention.
\end{abstract}

Keywords: larval density, House Index (HI), Container Index (CI), Bretau Index (BI)

\section{Introduction}

Dengue Hemorrhagic Fever (DHF) is the fastest spreading viral infection in the world. The World Health Organization (WHO) reports the incidence of DHF has increased dramatically in the past 50 years, and this virus infection continues to spread to new countries both in rural and urban areas. Approximately 2 to 5 billion people live in dengue-endemic areas, and more than $70 \%$ are located in Southeast Asia and the Western Pacific Region. In 2013 Indonesia was the area that suffered from dengue fever in Southeast Asia. [1].

DHF sufferers were reported to be 129,650 in 34 provinces in Indonesia, and 1,071 of them died (Incidence Rate (IR) of 50.75 per 100,000 population and Case Fatality Rate (CFR) of $0.83 \%$ ) in 2015 . That number was higher compared to the previous year, namely 100,347 cases with a total of 907 deaths (IR is 39.8 per 100,000 population, and CFR is $0.90 \%$. [2].

It is known that in 2012 there were 127 cases of Dengue Hemorrhagic Fever in Mamuju District, and none died, in 2013 the number of dengue cases increased to 271 cases, 3 died, and in 2014 the number of dengue cases decreased to 75 people and 1 person died (Mamuju District Health Office). Also, in the work area of the Binanga Health Center, there are several villages, namely Binanga, Rimuku, Karema, and Mamunyu. It is known that in Mamunyu Village, DHF in 2014 were 17 cases and in 2015 starting from January to March the number of dengue cases began to decline, as many as 10 cases and none died [3]. 
To eradicate DHF, knowledge of the bionomic (habit) of Aedes aegypti mosquitoes in a certain area is needed to control mosquito populations. Several indicators have been known to determine the level of DHF transmission by measuring eggs, larvae, pupae, and adult mosquitoes associated with dengue cases in high endemic areas, low endemic areas, and dengue-free areas. These indicators include Container Index (CI), House Index (HI) and Breteau Index (BI) [4].

By knowing the above, the researchers would try to survey the density of Aedes aegypti mosquito larvae in Mamunyu Village, Mamuju Subdistrict, Mamuju Regency, West Sulawesi Province. The processor method used is the visual method. This survey was carried out by looking and noting whether or not there are larvae in every pool of water without taking the larvae regarding environmental conditions. In the eradication of dengue disease program, larvae survey is usually done using the visual method and the measures used as an indicator is the House Index, Container Index, and Breteau Index. After getting the results, then we can do an action to reduce the density of mosquitoes in that area.

\section{Research methods}

This research is a descriptive study with data collection through observation and survey on the density of Aedes aegypti larvae in its breeding places. The population in this study were all households in Mamunyu Village, Mamuju Subdistrict, Mamuju Regency, West Sulawesi Province with a population of 1,256 households. The sample in this study were 125 households in Mamunyu Subdistrict, Mamuju Subdistrict, using the random sampling technique.

\section{Results}

Based on the research that has been done in Mamunyu village of 125 houses and 1039 types of containers. The researchers obtained the following results:

Table 1. Containers distribution in Mamunyu village, Mamuju Regency.

\begin{tabular}{lll}
\hline Type of container & Quantity & Percentage (\%) \\
\hline Bucket & 236 & 23 \\
Flower pot & 171 & 16 \\
Plastic cup & 109 & 10 \\
Used bottle & 117 & 11 \\
Water reservoir & 249 & 24 \\
Bathtub & 68 & 6 \\
Coconut shell & 38 & 4 \\
Tree branches & 22 & 2 \\
Used can & 3 & 1 \\
Used tire & 26 & 3 \\
Total & 1039 & 100 \\
\hline
\end{tabular}

Table 2. Aedes Aegypti larvae distribution based on container in Mamunyu village, Mamuju Regency.

\begin{tabular}{lll}
\hline Type of container & Quantity & Percentage (\%) \\
\hline
\end{tabular}




\begin{tabular}{lll}
\hline Bucker & 1 & 4 \\
Flowerpot & 4 & 16 \\
Water reservoir & 7 & 28 \\
Bathtub & 4 & 16 \\
Coconut shell & 1 & 4 \\
Tree branches & 2 & 8 \\
Used can & 1 & 4 \\
Used tire & 5 & 20 \\
Total & 25 & 100 \\
\hline
\end{tabular}

Table 3 . Index of Aedes Aegypt Larvae in Mamunyu Village, Mamuju Subdistrict, Mamuju Regency.

\begin{tabular}{llllllll}
\hline Checked & Total & Larvae & & HI & CI & BI & DF \\
\hline & & & & & & & $2-4$ \\
House & 125 & 20 & 105 & 16 & & & $\begin{array}{l}\text { (Moderate } \\
\text { Container }\end{array}$ \\
\hline
\end{tabular}

In this study, for the index of the Aedes Aegypti larvae in Mamunyu Subdistrict, Mamuju Regency we obtained the HI rate of $16 \%$, the number of $\mathrm{HI}$ found was categorized as high risk whereas CI numbers were 2.4 and categorized as low risk. For BI values, 20 were obtained and categorized as low risk. This larvae density when associated with using WHO vector density figure (DF), then Mamunyu Village is on a scale of 2-4, and according to WHO, density figure 1-4 is medium density category [5].

The results of the study in Mamunyu Subdistrict, Mamuju District, found positive larval homes of 20 houses $(16 \%)$. Based on WHO indicators, an area is said to be at high risk if it has a $\mathrm{HI}$ value of $\geq 5 \%$, while a low risk if the $\mathrm{HI}$ value is $<1 \%$. The higher the HI value, the higher the risk of transmission of DHF.[5]. So the Mamunyu Village area of Mamuju Regency is categorized as an area with a high risk of transmission. Factors that can influence the high $\mathrm{HI}$ value are the behavior and lack of people participation in mosquito nest eradication activities (PSN).

The results of this study are in line with the research of Tiya Taslisia, et al. (2018) who obtained an HI value of 57\% in Salido Village, IV Subdistrict, Jurai, Pesisir Selatan District, and Habibie et al (2017) research, which obtained 38\% HI value in Payakumbuh Ibuh Village which has high criteria HI that means the density in Ibuh Village is enough to facilitate the development of DHF [6].

The drainage of water reservoirs needs to be carried out regularly at least once a week so that mosquitoes cannot breed in reservoirs and grow into adult mosquitoes. If the $3 \mathrm{M}$ PSN is implemented by the entire community, then the population of Aedes Aegypti mosquitoes can be reduced as low as possible, so that the transmission of DHF does not occur. [5], [7].

This is in line with the research conducted by Muh. Saleh, et al. (2018) which said that there was a relationship between draining water reservoirs and the existence of larvae in Pancana health centers where respondents who did not drain their bath tubs were found Aedes Aegypti larvae, 24 of 27 respondents with a percentage of $14.8 \%$. Draining water reservoirs at least once a week can reduce the breeding grounds for Aedes Aegypti larvae. Because in the mosquito's life cycle, it is known that the Aedes Aegypti larvae can develop in 6-8 days. [6] Therefore, draining water reservoirs once a week affects the possibility of DHF occurrence. 
The risk of DHF transmission in Mamunyu Village, Mamuju Regency is also supported by the number of containers that can become a breeding ground for Aedes Aegypti mosquitoes. The containers such as water reservoirs, buckets, flower pots, plastic cups, used tires, bottles, bathtubs, and used cans both inside and outside the houses. These water reservoirs are environmental risk factors for DHF transmission. Because if its presence is not considered properly, it can be a breeding ground for mosquito larvae [8].

Container Index (CI) shows the number of reservoirs that are larval positive from the number of water reservoirs examined. The CI value obtained in this study was $2.40 \%$ and categorized as low risk. If an area has a $\mathrm{CI} \geq 5 \%$, it means high risk, and if the $\mathrm{CI}$ is $\leq 5 \%$, it means a low risk of DHF [4].

In this study, the most common type of container were buckets, which were located inside and outside of rooms and functioned as water reservoirs, but only 1 larva was found among those bucket containers. This happened because the bucket is easy and often cleaned because of its small size, so it does not allow water to be stored for long whereas containers with quite a lot of larvae (where 7 larvae were found ) were water reservoirs consisting of barrel, basin, drums and jerry cans. These reservoirs are hard to clean and can store a huge amount of water so the drainage frequency was low, and this allows for the breeding of Ae. Aegypti Mosquitos. Furthermore, containers that also contain a lot of larvae are used tires. The used tires are stacked for multiple purposes, but without disruption, it causes a problem because it can be a breeding ground for Ae.aegypti mosquito larvae.

The results of Sari's research, et al. (2012) say that brushing the wall of a water reservoir is intended to remove mosquito eggs [9]. The drainage of water reservoirs by emptying and replacing them with new water is not enough because it cannot clean the walls from the dirt, including mosquito eggs which are most likely still attached to the walls of water reservoirs. The sticking egg will later develop into larvae and adult mosquitoes.

According to WHO (2005), the availability of lids in water reservoirs is very necessary to reduce the number of mosquitoes that land on water reservoirs in addition to draining water reservoirs. If people realize how important a cover is for water reservoirs, then the existence of Ae. aegypti larvae can be eradicated. Based on the observations in this study, some containers containing larvae did not have coverings. These include used tires, bathtubs, and the basin. And because it didn't have lids, it could become a breeding ground for Ae. Aegypti mosquitos. So that closing the water reservoir tightly is essential to reduce the number of mosquitoes that land on the water reservoir. This is in line with research conducted by Muh. Saleh, et al. (2018) which states that there was a relationship between closing water reservoirs with the presence of Ae larvae. aegypti in the Pancana Health Center Work Area.

Bretau Index (BI) is the number of positive larval water reservoirs per 100 houses tested. $\mathrm{BI}$ is the best index for estimating vector density because BI combines houses with containers. [2]. If an area has a BI value of $\geq 30-50 \%$, it is said to be a high risk of DHF transmission and if the $\mathrm{BI}$ value is in a range of $5-20 \%$ it is said to be a low risk of dengue transmission. [4]. The value of BI in Mamunyu Village was $20 \%$, so it is categorized as a low risk of dengue transmission.

From the percentage that has been obtained in the Breteau Index, there is a potential cause of Dengue Hemorrhagic Fever due to the presence of Aedes aegypti mosquito larvae found in people's homes. After knowing this, it is expected that the community has the awareness to continue to take preventive measures to clean the environment so that there will no longer be cases of Dengue Hemorrhagic Fever. After seeing the results of the study of the value of House Index (HI), Container Index (CI), and Breteau Index (BI) in Mamuju Village, Mamuju Subdistrict, Mamuju Regency, West Sulawesi Province, although the CI and BI values are still 
in the low category, but it's still possible for the occurrence of DHF cases if it is not combated. So it must be a concern for the community because it does not rule out the possibility of transmission of Dengue Hemorrhagic Fever to occur again. In the effort to reduce the risk of dengue transmission, control of Ae.aegypti is a strategy that can be done at this time.

\section{Discussion}

The density of Ae.aegypti mosquito larvae in Mamunyu Village, Mamuju Subdistrict, Mamuju Regency is in the medium category (2-4). HI value is $16 \%$ and is in the high-risk category for dengue transmission, and for the CI value of $2.40 \%$ is included in the low-risk category, and the BI value is $20 \%$, categorized as low-risk of DHF transmission.

\section{Conclusion}

The foot arch type affects the energy expenditure during walking as measured by oxygen consumption. The least energy expenditure is in the normal foot type, and the greatest energy expenditure is in the low-arched foot type.

Acknowledgments. We want to say thank you to Poltekkes Kemenkes Mamuju, college students, instructors, and laboratories who have helped for this research.

\section{References}

[1] Linawati Alim, Farida Heriyani, Istiana Istiana.: Tingkat Kepadatan Jentik Nyamuk Aedes Aegypti Pada Tempat Penampungan Air Controllable Sites dan Disposable Sites di Sekolah Dasar Kecamatan Banjarbaru Utara Berkala Kedokteran.Vol.13, pp. 7-14. (2017)

[2] Tiya Taslisia, Selfi Renita Rusdji, Hasmiwati Hasmiwati.: Survey Entomologi, Maya Indeks, dan Status Kerentanan Larva Nyamuk Aedes Aegypti Trehadap Temephos Jurnal Kesehatan Andalas 2018. Vol. 7, pp. 8-9. (2018)

[3] Binanga Healh Center Binanga Health Center Data January - March 2015 Binanga.: Binanga Healh Center. (2015)

[4] World Health Organization (WHO).: A Review of Entomological Sampling Method and Indicators for Dengue Vector. (2003)

[5] Depkes RI.: Pencegahan dan Pemberantasan Demam Berdarah Dengue di Indonesia Jakarta Ditjen PP dan PL. (2005)

[6] Habibie AM .: Kepadatan Populasi Status Maya Indeks dan Uji Kerentanan Larva Aedes Aegypti di Kelurahan Ibuh Kota Payakumbuh Tahun 2017 Skripsi. pp. 9-18 (2017)

[7] Muhammad Saleh.: Hubungan Pemberantasan Sarang Nyamuk (PSN) dengan Keberadaan Jentik Nyamuk Aedes Aegypti di Wilayah Kerja Pancana Healh Center Kab. Barru Higiene 2018. Vol. 4, pp. 90-98. (2018)

[8] Depkes RI. Petunjuk Pemberantasan Sarang Nyamuk DBD di Perkotaan Ministry of Health of the Republic of Indonesia. (2004)

[9] Sari P .: Hubungan Kepadatan Jentik Aedes Aegypti dan Praktik PSN dengan Kejadian DBD di Sekolah Tingkat Dasar di Kota Semarang Jurnal Kesehatan Masyarakat 2012. Vol 1, pp. 413 -22. (2012) 